\title{
Effectiveness of hyperbaric oxygen and ozone applications in tissue healing in generated soft tissue trauma model in rats: an experimental study
}

\author{
Ali Osman Yıldırım, M.D.,, ${ }^{1}$ Mehmet Eryılmaz, M.D., ${ }^{2}$ Ümit Kaldırım, M.D., ${ }^{2}$ \\ Yusuf Emrah Eyi, M.D., ${ }^{3}$ Salim Kemal Tuncer, M.D., ${ }^{2}$ Murat Eroğlu, M.D., ${ }^{1}$ \\ Murat Durusu, M.D., ${ }^{2}$ Turgut Topal, M.D., ${ }^{4}$ Bülent Kurt, M.D., ${ }^{5}$ \\ Serkan Dilmen, M.D., ${ }^{6}$ Serkan Bilgiç, M.D., ${ }^{7}$ Muhittin Serdar, M.D. ${ }^{8}$
}

\author{
${ }^{1}$ Department of Emergency Medicine, GATA, Haydarpasa Military Hosital, Istanbul \\ ${ }^{2}$ Department of Emergency Medicine, GATA School of Medicine, Ankara \\ ${ }^{3}$ Department of Emergency Medicine, Hakkari Military Hospital, Hakkari \\ ${ }^{4}$ Department of Physiology, GATA School of Medicine, Ankara \\ ${ }^{5}$ Department of Pathology, GATA School of Medicine, Ankara \\ ${ }^{6}$ Department of Emergency Medicine, Elazig Military Hospital, Elazig \\ ${ }^{7}$ Department of Orthopaedics and Traumatology, GATA, Haydarpasa Military Hosital, Istanbul \\ ${ }^{8}$ Department of Biochemistry, GATA School of Medicine, Ankara
}

\begin{abstract}
BACKGROUND: Soft tissue trauma is a type of acute traumatic ischemia. We investigated in this study whether the edema, inflammation and ischemia caused by the trauma could be affected positively by hyperbaric oxygen (HBO) and ozone therapy.

METHODS: Soft tissue trauma was generated in a total of 63 adult male Sprague-Dawley rats. Subsequently, rats were divided into three groups. The first group was treated with ozone, the second group with $\mathrm{HBO}$, and the third group served as controls. Tissue and blood samples were taken at the end of the procedures. Tissue lipid peroxidation (LPO), superoxide dismutase (SOD), glutathione peroxidase (GSH-Px), inducible nitric oxide synthase (iNOS), heme oxygenase (HO)-I, and hypoxia-inducible factor (HIF)-I levels were detected. Hematoxylin-eosin staining was used to determine the inflammation and edema histopathologically.
\end{abstract}

RESULTS: We also detected HIF-I activity, which decreases when the oxygen concentration increases, HO-I activity, which has antiinflammatory effects, and iNOS activity, which releases in any type of acute case. We determined a statistically significant reduction in iNOS and LPO levels in both the HBO and Ozone groups. A significant decrease in inflammation was detected in both the Ozone and HBO groups compared with the Control group, and a significant decrease in edema was detected in all three groups.

CONCLUSION: We think that HBO and Ozone therapy have beneficial effects on biochemical and histopathological findings. Related clinical trials will be helpful in clarifying the effects.

Key words: Experimental; hyperbaric oxygen; ozone; soft tissue trauma.

Address for correspondence: Ali Osman Yildırım, M.D.

GATA Haydarpaşa Hastanesi, Acil Tıp Anabilim Dalı, İstanbul, Turkey

Tel: +90 216 - 5422020 E-mail: draliosmanyildirim@gmail.com

Qucik Response Code Ulus Travma Acil Cerrahi Derg

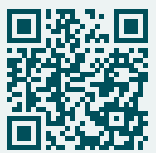

2014;20(3):167-175

doi: $10.5505 /$ tites.2014.09465

Copyright 2014

TJTES

\section{INTRODUCTION}

Soft tissue trauma (STT) is commonly encountered in emergency departments. STT defines lesions of the musculoskeletal system tissues other than bone. Lesions of these tissues represent the most commonly seen group of all sports injuries. ${ }^{[1]}$

Crush injuries or acute soft tissue injuries are an important health problem that can threaten the viability and function of 
the tissues. ${ }^{[2]}$ Crush injuries may also be defined as a kind of acute traumatic ischemia. The cause of ischemia is cutting or crushing of large vessels and stasis or reduction in microcirculation secondary to occlusion. As a result, adequate tissue perfusion to provide the metabolic needs of the tissue is not achieved. In the early phase of crush, tissue oxygen requirement is increased 20 -fold or more to provide good wound healing and control of infection. These metabolic needs cannot be provided without increased blood flow. When ischemia increases, the tissues cannot maintain the intracellular fluid content, because oxygen is required for active transport. Therefore, this process is accompanied by edema and inflammation. ${ }^{[3]}$

Hyperbaric oxygen ( $\mathrm{HBO}$ ) therapy is based on ventilating the patient with $100 \%$ oxygen over atmospheric pressure in a pressure-resistant room. HBO improves perfusion by increasing the level of free oxygen in the blood. Cell viability, energy production, and the production of collagen, which is important in wound healing, is thereby maintained. ${ }^{[4]}$

Ozone is a molecule consisting of three oxygen atoms. Ozone therapy is administration of a certain amount of oxygen/ozone mixture into body cavities or the circulatory system. Ozone reduces the amounts of antioxidants in plasma by activating them. The hydrogen peroxide that occurs is responsible for the biological and therapeutic effects of ozone. The decrease in the antioxidant level and stimulating effect of hydrogen peroxide generate a shock effect on the body in the ozone contacting process. As a result of this effect, a variety of defense systems, including primarily antioxidant enzyme expression, are stimulated. Thus, resistance to the oxidative processes increases. One of the first effects of hydrogen peroxide, which is thought to be one of the molecules responsible for the therapeutic activity of ozone, is slipping the hemoglobin-oxygen dissociation curve to the right and releasing oxygen to the tissues easily by increasing 2,3-diphosphoglycerate levels in red blood. ${ }^{[5]}$ The situation emerging during ozone therapy may be interpreted as increased tissue partial oxygen pressure is provided biochemically with ozone.

Patients with STT admit with complaints such as swelling, limitation of movement and pain. There are various approaches to the treatment of these patients, who are diagnosed after excluding bone and other pathologies based on physical examination and imaging. Support of the foot and ankle with materials such as plaster, splints and bandages, elevation, cold application, topical non-steroidal inflammationsuppressing drugs, vascular dilators, blood clot-dissolving drugs, and antioxidants are the commonly used treatment methods for soft tissue edema, ischemia and inflammation. Demonstration of the effectiveness of $\mathrm{HBO}$ and ozone therapy in STT may provide new perspectives on this issue. Thus, the effectiveness of $\mathrm{HBO}$ and ozone in STT was investigated in this study.

\section{MATERIALS AND METHODS}

The study was approved by the decision of GATA Command Ethics Committee for Animal Experiments on 3 March 201 I (decision 20II/II). Animals were supplied by GATA - Research and Development Center - Department of Experimental Animals, and were kept in the same laboratory conditions during the study. The animals were fed with commercial rat chow and tap water.

In this study, a total of 63 adult male Sprague-Dawley rats weighing $230 \pm 20 \mathrm{~g}$ were used. The rats were divided into a total of three groups of 21 rats each using 'simple random sampling' method. Initially, experimental STT was performed in each group. The ozone procedure was performed in one group (Ozone+STT group), the HBO procedure in another (HBO+STT group), and the third group served as controls (Table I). On the Ist, 3rd and 7th days, the samples were taken from seven rats randomly in each group, and results were compared at the different time points.

\section{Experimental Acute Soft Tissue Injury Model}

The animals were anesthetized with a combination of intraperitoneal (IP) ketamine $(20-40 \mathrm{mg} / \mathrm{kg})$ and xylazine (4-8 $\mathrm{mg} / \mathrm{kg}$ ). The subjects were fixed in the prone position, the rear leg was shaved, and the trauma application location was marked with a tissue pen (Fig. Ia). The STT was created using a $0.5 \mathrm{~kg}$ weight released for free fall movement from a $45 \mathrm{~cm}$ height, in a $3 \mathrm{~cm}$ diameter plastic tube, at a $90^{\circ}$ angle, on to the left rear leg of the rat (Fig. Ib).

\section{Hyperbaric Oxygen Therapy}

For the application of $\mathrm{HBO}$, a specially designed and manufactured cylindrical hyperbaric chamber, with a diameter of 40 $\mathrm{cm}$ and length $60 \mathrm{~cm}$, maintained at T.S.K. 800 Main Warehouse and Factory Command (Etimesgut, Ankara), was used. The chamber had a chromium, nickel and steel mixture body and had been tested for resistance to 10 ATA pressure. I.5-2 $\mathrm{L} / \mathrm{min}$ flow rate of oxygen input into the chamber was provided using tubes containing pure oxygen under high pressure and obtained from GATA - Biomedical Clinical Engineering Center - Medical Gases Department. After the animals in the $\mathrm{HBO}+\mathrm{STT}$ group were placed in the chamber, HBO therapy was applied for 2 hours/day under 2.5 ATA application pres-

Table I. Working groups

\begin{tabular}{llll}
\hline Groups & \multicolumn{3}{c}{ Days } \\
\cline { 2 - 4 } & Ist day & 3rd day & 7 th day \\
\hline Ozone + STT & 7 rats & 7 rats & 7 rats \\
HBO + STT & 7 rats & 7 rats & 7 rats \\
STT (Control) & 7 rats & 7 rats & 7 rats \\
\hline
\end{tabular}



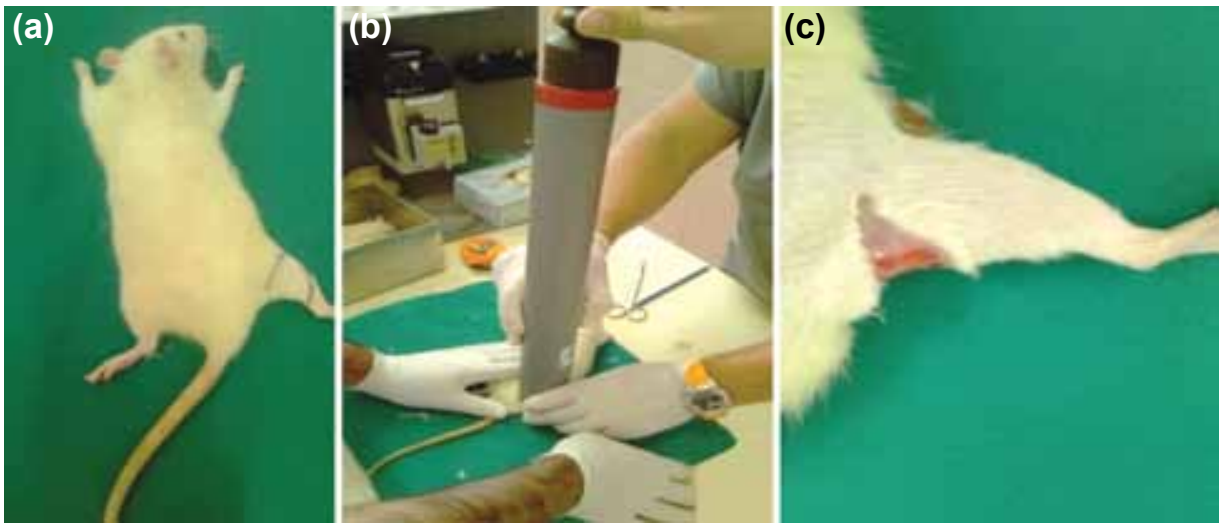

Figure 1. (a, b) Procedures for soft tissue trauma and (c) tissue sampling.

sure and with fixed oxygen amount. At the end of the session, the chamber was returned to environment pressure at a slower rate. This procedure was repeated on days 3 and 7 . After HBO therapy, a subgroup of animals (on days I, 3 and 7) were sacrificed.

\section{Ozone Application}

An ozone/oxygen mixture of $0.7 \mathrm{~g} / \mathrm{kg}$ was administered IP to the rats in the ozone group on days I, 3 and 7 . Ozone is created by an ozone generator (OZONOSAN Photonic 1014, Hans GmbH Nordring \& Iffezheim, Germany), in which a spectrometer was placed that allowed the operator to control real-time gas flow rate and ozone concentration. The ozone flow rate was kept constant at $60 \mathrm{mg} / \mathrm{ml}$ concentration, $97 \%$ oxygen $+3 \%$ ozone gas mixture at $3 \mathrm{~L} / \mathrm{min}$.

\section{Sampling}

After creating an experimental model of STT, tissue and blood samples were taken from each subgroup of 7 rats on the Ist, 3rd and 7th days. After anesthesia, required blood samples were taken from the inferior vena cava. Traumatic tissue samples were excised and placed in 10\% formalin for histopathological analysis. A portion of traumatic tissue was frozen with liquid nitrogen and stored at $-80^{\circ} \mathrm{C}$ deep freeze for subsequent biochemical assessments (Fig. IC).

\section{Biochemical Analysis}

Routine biochemistry levels to follow the general condition of the animal, tissue lipid peroxidation (LPO) levels to detect the level of tissue oxidative stress, and tissue superoxide dismutase (SOD) and glutathione peroxidase (GSH-Px) enzyme levels to detect antioxidant system functioning were measured. In addition, hypoxia-inducible factor (HIF-I) and heme oxygenase (HO-I) levels were measured to determine the recovery of hypoxic tissues, and inducible nitric oxide synthase (iNOS) levels were measured to determine wound healing.

Table 2. Comparison of tissue enzyme levels of all groups according to time points

\begin{tabular}{|c|c|c|c|c|c|c|}
\hline & $\begin{array}{c}\text { LPO } \\
\text { nmol/g } \\
\text { Mean. } \pm S D\end{array}$ & $\begin{array}{c}\text { SOD } \\
\text { U/mg } \\
\text { Mean. } \pm S D\end{array}$ & $\begin{array}{c}\text { HO-I } \alpha \\
\mathrm{nmol} / \mathrm{g} \\
\text { Mean. } \pm \text { SD }\end{array}$ & 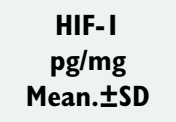 & $\begin{array}{c}\text { iNOS } \\
\text { IU/mg } \\
\text { Mean. } \pm \text { SD }\end{array}$ & $\begin{array}{c}\text { GSH-PX } \\
\text { nmol/min/mg } \\
\text { Mean. } \pm S D\end{array}$ \\
\hline Ist day & $69.54 \pm 14.5$ & $7.55 \pm 3.2$ & II69.8 \pm 251.2 & $73.34 \pm 22.15$ & $38.70 \pm 16.6$ & $|0.73 \pm 2.3|$ \\
\hline 3rd day & $53.60 \pm 12.6$ & $6.15 \pm 2.48$ & $1091.71 \pm 243.8$ & $37.92 \pm 15.53$ & $31.73 \pm 9.15$ & $9.20 \pm 3.05$ \\
\hline 7th day & $43.98 \pm 20.54$ & $5.37 \pm 2.29$ & $838.85 \pm 348.44$ & $22.74 \pm 8.87$ & $24.42 \pm 6.35$ & $9.80 \pm 3.50$ \\
\hline $\mathrm{P}$ & 0.028 & 0.337 & 0.104 & $<0.001$ & 0.097 & 0.639 \\
\hline Ist day & $52.97 \pm 16.13$ & $23.44 \pm 9.77$ & $1191 \pm 322.90$ & $50.35 \pm 17.35$ & $70.39 \pm 23.31$ & $27.50 \pm 9.94$ \\
\hline 3rd day & $|5.29 \pm 5.1|$ & $18.65 \pm 7.40$ & $1105.71 \pm 262.7$ & $40.61 \pm 13.92$ & $46.73 \pm 17.27$ & $6.86 \pm 3.05$ \\
\hline 7th day & $17.46 \pm 8.92$ & $|1.7 \pm 1.9|$ & $866.7 I \pm 290.01$ & $28.52 \pm|0.5|$ & $27.4 \pm 9.91$ & $7.11 \pm 2.87$ \\
\hline$P$ & $<0.001$ & 0.023 & 0.128 & 0.033 & 0.001 & $<0.001$ \\
\hline Ist day & $62.54 \pm 14.74$ & $18.36 \pm 6.53$ & $1067.57 \pm 29 \mid .92$ & $56.48 \pm 32.01$ & $79.25 \pm 23.96$ & $12.25 \pm 3.19$ \\
\hline 3 rd day & $33.61 \pm 9.84$ & $10.92 \pm 4.36$ & $7|5.50 \pm 178.6|$ & $35.15 \pm 12.09$ & $43.08 \pm 23.21$ & $9.49 \pm 2.48$ \\
\hline 7th day & $24.29 \pm 7.57$ & $4.05 \pm 1.87$ & $969.33 \pm 356.1$ & $31.58 \pm 10.14$ & $16.38 \pm 3.9$ & $4.92 \pm 2.25$ \\
\hline $\mathrm{P}$ & $<0.001$ & $<0.001$ & 0.109 & 0.105 & $<0.001$ & 0.001 \\
\hline
\end{tabular}




\section{Histopathological Evaluation}

After trauma and administration of $\mathrm{HBO}$ and ozone treatment for 7 days, edema, inflammation and necrosis in tissue were evaluated and scored by an experienced pathologist. Injured skeletal muscle and adipose tissue were extracted from the rear thigh. Tissues were fixed in $4 \%$ buffered formaldehyde. Tissues were sampled completely, paraffin blocks were obtained, and 5 micron thickness slides were prepared. Slides were stained with hematoxylin-eosin. Evaluation and scoring were performed by light microscope (Nikon, E600, Tokyo, Japan).

Histological scoring was as follows:

I. Edema: absent: 0 , mild: I+, moderate: $2+$, intense: $3+$

2. Inflammation: absent: 0 , mild: $I+$, moderate: $2+$, intense: $3+$

3. Necrosis: absent: 0 , mild: I+ (a few muscle fibers), moderate: 2+ (between score I and 3), intense: 3+ (many muscle fibers)
As shown in Table 4, the minimum score was 0 and maximum score was 9.

\section{Statistical Analysis}

The numbers (\%) for defining the discrete data points and median (25\%-75\%) values for defining continuous data were used. The Kruskal-Wallis test was used in all group comparisons, and then Mann-Whitney U-test was used to compare the groups in pairs that showed significant results. Chi-square or Fisher's exact test was used in comparison of the discrete data between the two groups. The simultaneous changes in continuous variables were assessed by Spearman relevant coefficient. $\mathrm{p}<0.05$ values were considered significant.

\section{RESULTS}

\section{Biochemical Results}

In tissue samples analysis, a significant decrease in LPO levels was observed in the $\mathrm{HBO}$ and Ozone groups compared to
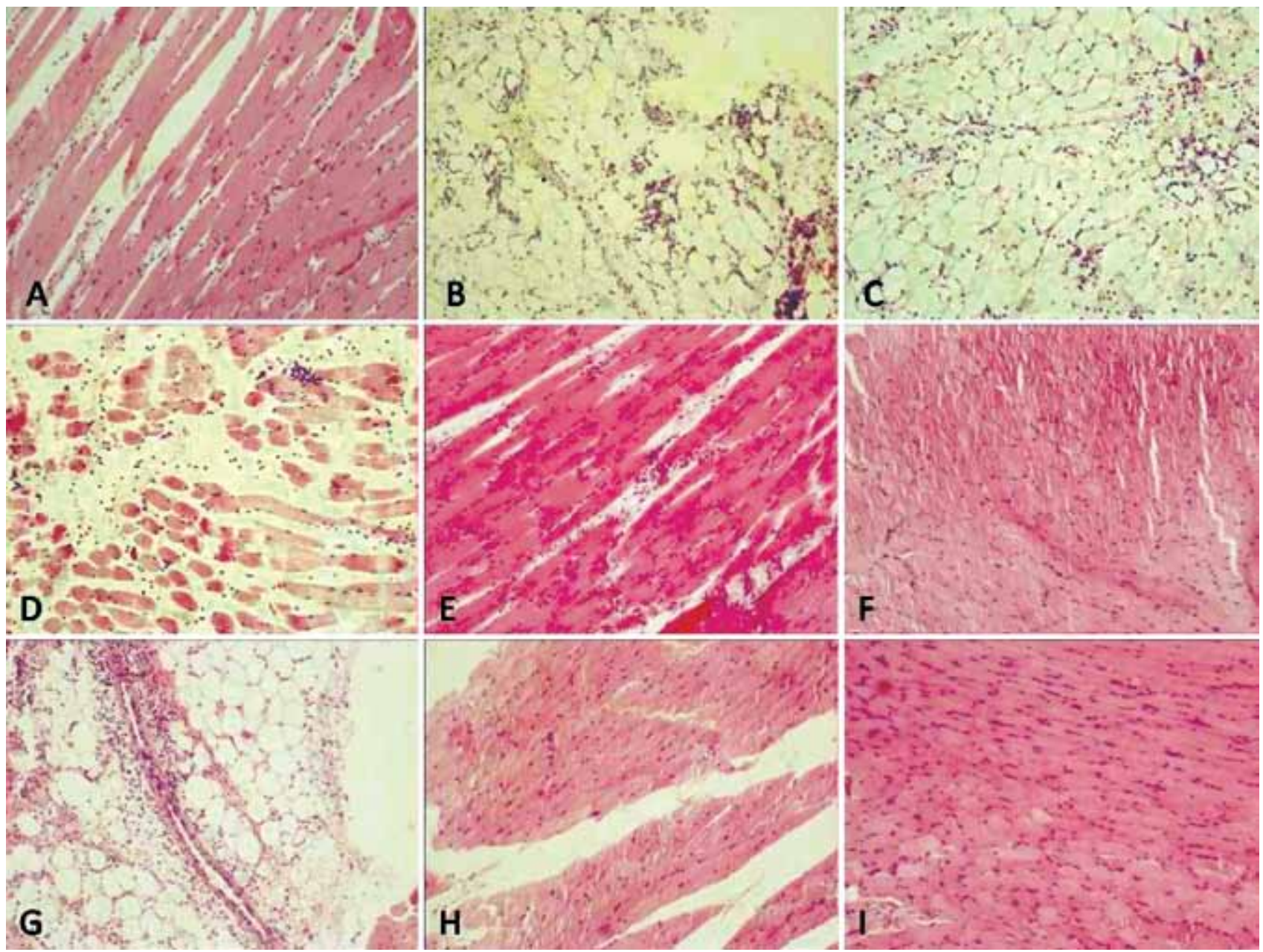

Figure 2. Intense edema and inflammation between muscle fibers and a few necrotic muscle fibers (Control group, 1st day) (a). Moderate edema and inflammation in adipose tissue (HBO group, 1st day) (b). Moderate edema and inflammation in adipose tissue (Ozone group, 1st day) (c). Intense edema and inflammation (Control, 3rd day) (d). Moderate edema and inflammation in muscle tissue (HBO, 3rd day) (e). Mild inflammation in muscle tissue (f). Mild inflammation in muscle tissue (Ozone 3rd day) (g). Moderate edema and inflammation in adipose tissue (Control, 7th day) (h). Mild inflammation and edema (HBO, 7th day) (I). 
Table 3. Comparison of serum enzyme level of Control, $\mathrm{HBO}$ and Ozone groups according to the Ist and 7th days

\begin{tabular}{|c|c|c|c|c|c|c|}
\hline & $\begin{array}{c}\text { LPO } \\
\text { nmol/L } \\
\text { Mean. } \pm S D\end{array}$ & $\begin{array}{c}\text { SOD } \\
\text { U/ml } \\
\text { Mean. } \pm S D\end{array}$ & $\begin{array}{c}\text { HO-I } \alpha \\
\text { ng/ml } \\
\text { Mean. ISD }\end{array}$ & 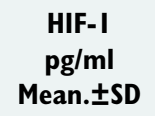 & 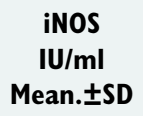 & $\begin{array}{c}\text { GSH-PX } \\
\text { nmol/min/ml } \\
\text { Mean. } \pm \text { SD }\end{array}$ \\
\hline \multicolumn{7}{|l|}{ Control } \\
\hline Ist day & $4.99 \pm 1.03$ & $0.96 \pm 0.40$ & $280.10 \pm 69.81$ & $15.73 \pm 2.90$ & $3.80 \pm 0.91$ & $1.67 \pm 0.34$ \\
\hline 7th day & $2.85 \pm 0.91$ & $0.24 \pm 0.16$ & $201.33 \pm 20.64$ & $13.15 \pm 3.64$ & $3.32 \pm 0.94$ & $0.80 \pm 0.28$ \\
\hline$P$ & 0.001 & 0.001 & 0.014 & 0.168 & 0.354 & $<0.001$ \\
\hline \multicolumn{7}{|l|}{$\mathrm{HBO}$} \\
\hline Ist day & $3.07 \pm 0.72$ & $1.90 \pm 0.38$ & $410.94 \pm 97.27$ & $25.14 \pm 9.19$ & $4.31 \pm 0.62$ & $1.56 \pm 0.49$ \\
\hline 7th day & $1.37 \pm 0.40$ & $2.66 \pm 1.06$ & $268.86 \pm 80.24$ & $22.28 \pm 3.25$ & $4.02 \pm 0.92$ & $1.81 \pm 0.28$ \\
\hline$P$ & $<0.001$ & 0.102 & 0.011 & 0.453 & 0.499 & 0.270 \\
\hline \multicolumn{7}{|l|}{ OZONE } \\
\hline Ist day & $1.66 \pm 0.47$ & $1.74 \pm 0.63$ & $439.15 \pm 58.12$ & $34.65 \pm 7.45$ & $2.46 \pm 0.68$ & $1.52 \pm 0.30$ \\
\hline 7th day & $1.35 \pm 0.25$ & $2.70 \pm 0.58$ & $|43.45 \pm 4| .94$ & $7.89 \pm 3.67$ & $4.79 \pm 1.57$ & I. $20 \pm 0.7 \mid$ \\
\hline$P$ & 0.175 & 0.017 & $<0.001$ & $<0.001$ & 0.004 & 0.307 \\
\hline
\end{tabular}

the Control group on days I, 3 and 7. There was a significant decrease in SOD, GSH-Px and iNOS levels only in the treatment groups (Table 2). The values of all parameters in serum samples were measured as significantly lower on the 7th day compared to the Ist day except in SOD/GSH-Px in the HBO group and in SOD/iNOS in the Ozone group (Table 3). The values of LPO, HIF-I, HO-I $\alpha$, GSH-Px, SOD, and iNOS from tissue samples are presented in Table 2, and the values of LPO, HIF-I, HO-I $\alpha$, GSH-Px, SOD, and iNOS from serum samples are presented in Table 3.

With regard to binary comparisons of the parameters between the Control and $\mathrm{HBO}$ groups for tissue on the Ist day, SOD, iNOS and GSH-Px levels of the HBO group were sig-

Table 4. Comparison of edema, necrosis and inflammation in the Control, HBO and Ozone groups according to days I, 3 and 7

\begin{tabular}{|c|c|c|c|c|c|c|c|c|c|c|c|c|}
\hline & \multicolumn{4}{|c|}{ Control } & \multicolumn{4}{|c|}{ HBO } & \multicolumn{4}{|c|}{ Ozone } \\
\hline & \multicolumn{3}{|c|}{ Days } & \multirow[b]{2}{*}{$\mathbf{p}$} & \multicolumn{3}{|c|}{ Days } & \multirow[b]{2}{*}{$\mathbf{p}$} & \multicolumn{3}{|c|}{ Days } & \multirow[b]{2}{*}{$\mathbf{p}$} \\
\hline & Ist & 3rd & 7th & & Ist & $3 r d$ & 7 th & & Ist & $3 r d$ & 7 th & \\
\hline \multicolumn{13}{|l|}{ Edema } \\
\hline 0 & 0 & 0 & 0 & $<0.001$ & 0 & 0 & 0 & $<0.001$ & 0 & 7 & 7 & $<0.001$ \\
\hline$(+)$ & 0 & 0 & 0 & & 0 & 0 & 7 & & 0 & 0 & 0 & \\
\hline$(++)$ & 0 & 0 & 7 & & 7 & 7 & 0 & & 7 & 0 & 0 & \\
\hline$(+++)$ & 7 & 7 & 0 & & 0 & 0 & 0 & & 0 & 0 & 0 & \\
\hline \multicolumn{13}{|l|}{ Necrosis } \\
\hline 0 & 0 & 7 & 7 & $<0.001$ & 7 & 7 & 7 & $(*)$ & 7 & 7 & 7 & $(*)$ \\
\hline$(+)$ & 7 & 0 & 0 & & 0 & 0 & 0 & & 0 & 0 & 0 & \\
\hline$(++)$ & 0 & 0 & 0 & & 0 & 0 & 0 & & 0 & 0 & 0 & \\
\hline$(+++)$ & 0 & 0 & 0 & & 0 & 0 & 0 & & 0 & 0 & 0 & \\
\hline \multicolumn{13}{|c|}{ Inflammation } \\
\hline 0 & 0 & 0 & 0 & $(*)$ & 0 & 0 & 0 & $<0.001$ & 0 & 0 & 7 & $<0.001$ \\
\hline$(+)$ & 0 & 0 & 0 & & 0 & 0 & 7 & & 0 & 7 & 0 & \\
\hline$(++)$ & 7 & 7 & 7 & & 0 & 7 & 0 & & 7 & 0 & 0 & \\
\hline$(+++)$ & 0 & 0 & 0 & & 7 & 0 & 0 & & 0 & 0 & 0 & \\
\hline
\end{tabular}

(*) Chi-square test could not be applied. 
nificantly higher than in the Control group $(p<0.001, p=0.001$ and $\mathrm{p}<0.00 \mathrm{I}$, respectively). LPO and HIF-I levels of the HBO group were significantly lower than in the Control group $(p=0.023$ and $p=0.017$, respectively). On the $3 r d$ and 7 th days, LPO levels in the HBO group were significantly lower than in the Control group $(p<0.001$ and $p<0.001$, respectively), and SOD levels of the HBO group were significantly higher than in the Control group $(p<0.001$ and $p=0.027$, respectively). Differences in HIF-I, iNOS and GSH-Px levels between the $\mathrm{HBO}$ and Control groups were not statistically significant on the $3 r d$ and 7 th days. There was no statistically significant difference in $\mathrm{HO}-\mathrm{I} \alpha$ levels on the Ist, 3rd and 7th days between the Control and $\mathrm{HBO}$ groups.

With regard to binary comparisons of the parameters between the Control and Ozone groups for tissue, SOD and iNOS levels were significantly higher in the Ozone group than Control group on the Ist day $(p<0.001$ and $p<0.00$ I, respectively). LPO and HO-I $\alpha$ levels were significantly lower in the Ozone group than Control group on the 3rd day $(p=0.009$ and $p=0.023$, respectively). LPO and GSH-Px levels were significantly lower in the Ozone group than Control group on the 7 th day $(p=0.010$ and $p=0.048$, respectively). Differences in other parameters were not statistically significant between the Ozone and Control groups.

\section{Histopathological Findings}

In all groups, the total score was less on the 3rd and 7th days than on the Ist day. The Ist day score of the Ozone group was lower than the Ist day score of the Control and HBO groups. 7th day score of the Ozone group was lower than of the $\mathrm{HBO}$ group.

In the Control group, edema was intense on the Ist and 3rd days, but was moderate on the 7th day. The difference between Ist or 3rd vs. 7th day was statistically significant $(p<0.001)$. Inflammation was moderate on all days; therefore, chi-square test could not be applied. While necrosis was mild on the Ist day, it was absent on the 3rd and 7th days in the Control group, and this was also statistically significant $(p<0.001)$ (Table 4).

In the HBO group, edema was moderate on the Ist and 3rd days, but on the 7th day it was mild. Inflammation was intense, moderate and mild on the Ist, 3rd and 7th days, respectively. This decrease in the HBO group was statistically significant. However, necrosis was not seen in the HBO group on any day (Table 4).

In the Ozone group, edema was moderate on the Ist day, but absent on the 3rd and 7th days. Inflammation was moderate, mild and absent on the Ist, 3rd and 7th days, respectively. This decrease in the Ozone group was statistically significant $(p<0.001)$. Necrosis was not seen in this group (Table 4).
Examples of histopathological images of the Control and treatment groups are presented in Figure 2.

\section{DISCUSSION}

In the review of the literature about models of STT, there are methods created chemically (such as zymosan), by ultraviolet radiation and mechanically (or physically). The components of the immune system are also activated when trying to create an inflammation model using antigenic substances such as Freud adjuvant, carrageenan or zymosan. However, soft tissue injuries that occur in reality are usually sterile. There are also sterilized injury models created by ultraviolet exposure. [6] This injury model was developed on the model of traumatic brain injury studies in rats. ${ }^{[7,8]}$

There are various clinical studies in the literature about $\mathrm{HBO}$ effectiveness in STT treatment. The common view in these studies is that $\mathrm{HBO}$ is not effective in STT treatment. However, a review of the Cochrane Collaboration, published in 2009, expressed the limitations of the studies and the necessity for further, more comprehensive studies. Although the efficacy of ozone in the inflammatory process is known, we could not find any study in the literature on ozone use in STT except in lumbar disc herniation and orthopedic disorders including arthritis and rheumatic diseases. ${ }^{[9-19]}$ In their study, Brooke et al. performed HBO therapy in 21 collegiate volunteers who had exercise-induced muscle injury, and they concluded that HBO therapy is not an effective treatment in muscle injury. It was thought that this result could be attributed to the fact that it is not possible to standardize STT severity. One of the other factors that possibly contributes to unsuccessful $\mathrm{HBO}$ treatment is that structures such as muscle ligaments, tendons and fascia are also affected, and these structures have a much lower response to oxygen. ${ }^{[14]}$

Soolsma ${ }^{[20]}$ could find no evidence of a benefit of HBO treatment on delayed muscle pain treatment process in his grade 2 medial collateral ligament injuries study in 1996. Four studies published results showing that $\mathrm{HBO}$ had decreased pain significantly in patients at the end of 48 hours, but there was no evidence of improvement in muscle tension or decrease in edema. There was no difference between groups with regard to signs of edema and muscle tension. There was also no significant difference in clinical outcomes after 24 hours delayed HBO treatment in the study of Harrison and Staples. [1 1,14,21] The apparent incompatibility of these results with ours is thought to be due to use of ligament injury as a model and the limited response of ligaments to oxygen.

Ozone therapy has shown positive effects on wound healing, age-related macular degeneration, and ischemic and infectious diseases in case-analysis studies. In addition, it has been effectively applied in a variety of infectious diseases ranging from simple dental or mouth infections to hepatitis. ${ }^{[22,23]}$ 
The therapeutic effect of ozone, especially in pathophysiological situations due to an intense inflammatory process in which the immune system is forefront, is surprising. MartinezSanchez and colleagues ${ }^{[16]}$ applied HBO treatment to patients with diabetic foot, and they reported that wound healing was accelerated, length of hospital stay was shortened, control of blood sugar levels was better, and antioxidant enzyme levels were increased in the HBO treatment group when compared to the antibiotic treatment group. It has also been reported that injection of an oxygen/ozone mixture into the disc is useful in lumbar disc herniations. ${ }^{[17]}$ The studies have shown that ozone applications increase the secretion of platelet-derived growth factor (PDGF), transforming growth factor (TGF)-BI, and cytokines such as interleukin (IL)-8 from platelets. Kim et al. ${ }^{[18]}$ also showed the same results in their wound healing study. In that study, topically applied ozone increased PDGF, TGF and VEGF expression and accelerated wound healing in scar tissue. Koca et al. ${ }^{[19]}$ recently showed that inflammatory cytokines and oxidative stress decreased in both the ozone and $\mathrm{HBO}$ groups.

There are important studies in the literature about how the HBO application affects the antioxidant enzymes in various tissues in the organism. In one of them, Harabin and colleagues ${ }^{[24]}$ reported an increase in SOD activity in the lung and decrease in GSH-Px activity in brain and lung tissues in $\mathrm{HBO}$-applied rats and guinea pigs. There are other researches as well that report that HBO may lead to an increase in SOD activity. These results seem compatible with our study results.

Although an increase in antioxidant enzyme activities indicates an increase in free radical production, this increase has importance especially when these enzymes exceed the capacity. The lipid peroxidation, which is one of the most important harmful effects of free radicals, must be evaluated to assess the effect of increased free radical level. The best indicator of this is LPO. In our study, the decrease in LPO levels was statistically significant in the $\mathrm{HBO}$ group compared to the Control group on the Ist, 3rd and 7th days, and the decrease in LPO levels was insignificant on the Ist day and was statistically significant on the 3rd and 7th days. These values show that the decrease in LPO level was less in the Control group than in the Ozone and HBO groups. This situation may show that there is an intense oxidative stress that exceeds the capacity of antioxidant enzymes in the created trauma.

Organisms needing oxygen for life must have a physiological adaptation to hypoxia. In mammals, including humans, vasodilation, angiogenesis, increase in glucose transport, increase in glucolysis, and apoptosis are activated. In the treatment of tumors, antiangiogenesis reduces the tumor blood flow, causing the tumor cells to become resistant to chronic hypoxia. It has been found that the signaling pathway stimulated by hypoxia improves the acquired tolerance to chronic hypoxia. HIF-I $\alpha$ controls this by influencing apoptosis and regulating genes and vascular endothelial growth factor (VEGF). ${ }^{[26,27]}$ Reduction in oxygen in a region increases the production of the gene regulatory protein HIF-I. This protein increases VEGF production particularly affecting the VEGF gene promoter. The VEGF secreted by surrounding tissue increases vasculature by activating endothelial cells in this region. When the formation of new blood vessels occurs and the oxygen concentration increases, HIF-I activity and VEGF production decrease. ${ }^{[28]}$ In our study, there was a statistically significant decrease in the Control and HBO groups at the different time points. In the Ozone group, it was statistically insignificant. Decrease in the level of HIF-I between the Control and $\mathrm{HBO}$ groups was statistically significant on day I and was statistically insignificant on day 3 and day 7. Based on these findings, it is known that $\mathrm{HBO}$ therapy has a more active role than Ozone treatment in tissue oxygenation, especially in the early days of the trauma.

It has been reported that with application of ozone, the HO-I enzyme is also stimulated. The reason for the increase in this enzyme may be due to red blood cell hemolysis or ROT. HO-I is a microsomal enzyme involved in the demolition of heme ring, and the production is stimulated by an increase in oxidative stress, inflammatory cytokines and NO. This enzyme smashes the heme molecule in biliverdin and carbon monoxide (CO). Several studies performed in recent years showed that the HO-I enzyme had antioxidant, antiinflammatory and antiapoptotic properties. ${ }^{[29-31]}$ However, in one study it was demonstrated that induction of hem oxygenase is one of the protective mechanisms against oxidative stress in the pathogenesis of pulmonary disease. HO-I, the inducible form of $\mathrm{HO}$, catalyzes heme to bilirubin, and this causes free iron and $\mathrm{CO}$ production. ${ }^{[32]}$ In our study, change in $\mathrm{HO}-\mathrm{I}$ activity between groups was not significant according to time points. The protection of $\mathrm{HO}-\mathrm{I}$ levels is considered to be significant in our study, in which the enzyme levels were generally decreased.

iNOS that is released in any acute event (trauma, stress, acute inflammation, etc.) may have either a protective or detrimental effect on tissue. NO is important in wound healing. NO synthesis by macrophages continues for a long time in vitro. NO produced by structural NOS is necessary to maintain the normal physiological events. High NO concentrations produced by iNOS increase the damage. ${ }^{[33]}$ In short, the NO molecule may show either protective or damaging effects in acute inflammatory events. In burning wounds as well, the level of iNOS increases immediately after the trauma. Koca et al. ${ }^{[19]}$ created skeletal muscle ischemia-reperfusion injury in rats, and reported that $\mathrm{HBO}$ treatment decreased MDA and NOS levels, and significantly increased GSH-Px enzyme activity. These findings seem to be compatible with our study. On histopathologic examination of the tissues exposed to trauma, the inflammation was more significantly decreased in the treatment groups than the Control group. The histopathological findings support the biochemical findings. 
In conclusion, as a result of the study findings and the literature review, we find that there are laboratory results showing that ozone and $\mathrm{HBO}$ reduce oxidative stress, improve tissue healing and increase tissue partial oxygen pressure. These results are supported by the significant reduction in inflammation and edema on the histopathological examination in the treatment groups.

In this study, the ozone and HBO treatments in STT were considered to be of benefit based on the biochemical and histopathological findings. However, we were unable to determine any clear result that revealed the superiority of either $\mathrm{HBO}$ or ozone. Further studies on this subject, which is a popular topic in the treatment of soft tissue injuries, will provide new insights.

\section{Conflict of interest: None declared.}

\section{REFERENCES}

1. Yucesir I, Bayraktar B. Soft tissue injuries and ;rinciples of healing. Türkiye Klinikleri J Orthop \& Traumatol-Special Topics 2010;3:24-8.

2. Bywaters EG, Beall D. Crush injuries with impairment of renal function. 1941. J Am Soc Nephrol 1998;9:322-32.

3. Mabvuure NT, Malahias M, Hindocha S, Khan W, Juma A. Acute compartment syndrome of the limbs: current concepts and management. Open Orthop J 2012;6:535-43.

4. Feldmeier JJ. Hyperbaric oxygen 2003: Indications and results: The Hyperbaric Oxygen Therapy Committee Report. Undersea and Hyperbaric Medical Society, Inc., Kensington, MD, 2003.

5. Bocci V. How does ozone act? How and why can we avoid ozone toxicity? In: Bocci V, editor. Ozone; A new medical drug. Dordrecht: Springer; 2005. p. 19-28.

6. Davies SL, Siau C, Bennett GJ. Characterization of a model of cutaneous inflammatory pain produced by an ultraviolet irradiation-evoked sterile injury in the rat. J Neurosci Methods 2005;148:161-6.

7. Dixon CE, Clifton GL, Lighthall JW, Yaghmai AA, Hayes RL. A controlled cortical impact model of traumatic brain injury in the rat. J Neurosci Methods 1991;39:253-62.

8. Tavazzi B, Signoretti S, Lazzarino G, Amorini AM, Delfini R, Cimatti $\mathrm{M}$, et al. Cerebral oxidative stress and depression of energy metabolism correlate with severity of diffuse brain injury in rats. Neurosurgery 2005;56:582-9.

9. Kranke P, Bennett MH, Martyn-St James M, Schnabel A, Debus SE. Hyperbaric oxygen therapy for chronic wounds. Cochrane Database Syst Rev 2012;4:CD004123.

10. Babul S, Rhodes EC, Taunton JE, Lepawsky M. Effects of intermittent exposure to hyperbaric oxygen for the treatment of an acute soft tissue injury. Clin J Sport Med 2003;13:138-47.

11. Staples JR, Clement DB, Taunton JE, McKenzie DC. Effects of hyperbaric oxygen on a human model of injury. Am J Sports Med 1999;27:6005.

12. Germain G, Delaney J, Moore G, Lee P, Lacroix V, Montgomery D. Effect of hyperbaric oxygen therapy on exercise-induced muscle soreness. Undersea Hyperb Med 2003;30:135-45.

13. Bennett MH, Feldmeier J, Hampson N, Smee R, Milross C. Hyperbaric oxygen therapy for late radiation tissue injury. Cochrane Database of Systematic Reviews 2009, Issue 3. Art. No: CD005005.
14. Harrison BC, Robinson D, Davison BJ, Foley B, Seda E, Byrnes WC. Treatment of exercise-induced muscle injury via hyperbaric oxygen therapy. Med Sci Sports Exerc 2001;33:36-42.

15. Bocci V. The case for oxygen-ozonetherapy. Br J Biomed Sci 2007;64:449.

16. Martínez-Sánchez G, Al-Dalain SM, Menéndez S, Re L, Giuliani A, Candelario-Jalil E, et al. Therapeutic efficacy of ozone in patients with diabetic foot. Eur J Pharmacol 2005;523:151-61.

17. Muto M, Ambrosanio G, Guarnieri G, Capobianco E, Piccolo G, Annunziata $G$, et al. Low back pain and sciatica: treatment with intradiscalintraforaminal O(2)-O (3) injection. Our experience. [Article in English, Italian] Radiol Med 2008;113:695-706. [Abstract]

18. Kim HS, Noh SU, Han YW, Kim KM, Kang H, Kim HO, et al. Therapeutic effects of topical application of ozone on acute cutaneous wound healing. J Korean Med Sci 2009;24:368-74.

19. Koca K, Yurttas Y, Bilgic S, Cayci T, Topal T, Durusu M, et al. Effect of preconditioned hyperbaric oxygen and ozone on ischemia-reperfusion induced tourniquet in skeletal bone of rats. J Surg Res 2010;164:83-9.

20. Soolsma SJ. The effect of intermittent hyperbaric oxygen on short term recovery from grade II medial collateral ligament injuries. Thesis (1996), University of British Columbia, Vancouver.

21. Mekjavic IB, Exner JA, Tesch PA, Eiken O. Hyperbaric oxygen therapy does not affect recovery from delayed onset muscle soreness. Med Sci Sports Exerc 2000;32:558-63.

22. Stübinger S, Sader R, Filippi A. The use of ozone in dentistry and maxillofacial surgery: a review. Quintessence Int 2006;37:353-9.

23. Nogales CG, Ferrari PH, Kantorovich EO, Lage-Marques JL. Ozone therapy in medicine and dentistry. J Contemp Dent Pract 2008;9:75-84.

24. Harabin AL, Braisted JC, Flynn ET. Response of antioxidant enzymes to intermittent and continuous hyperbaric oxygen. J Appl Physiol (1985) 1990;69:328-35.

25. Oter S, Korkmaz A, Topal T, Ozcan O, Sadir S, Ozler M, et al. Correlation between hyperbaric oxygen exposure pressures and oxidative parameters in rat lung, brain, and erythrocytes. Clin Biochem 2005;38:706-11.

26. Carmeliet P, Dor Y, Herbert JM, Fukumura D, Brusselmans K, Dewerchin M, et al. Role of HIF-1alpha in hypoxia-mediated apoptosis, cell proliferation and tumour angiogenesis. Nature 1998;394:485-90.

27. Communal C, Sumandea M, de Tombe P, Narula J, Solaro RJ, Hajjar RJ. Functional consequences of caspase activation in cardiac myocytes. Proc Natl Acad Sci U S A 2002;99:6252-6.

28. Alberts B, Johnson A, Lewis J, Raff M, Roberts K, Walter P. Histology: The lives and deaths of cells in tissues. In: Alberts B, Johnson A, Lewis J, Raff M, Roberts K, Walter P, editors. Molecular biology of the cell. 4th ed. New York: Garland Science; 2002, p. 1259-312.

29. Bocci V, Aldinucci C, Mosci F, Carraro F, Valacchi G. Ozonation of human blood induces a remarkable upregulation of heme oxygenase- 1 and heat stress protein-70. Mediators Inflamm 2007;2007:26785.

30. Bach FH. Heme oxygenase-1: a therapeutic amplification funnel. FASEB J 2005;19:1216-9.

31. Otterbein LE, Soares MP, Yamashita K, Bach FH. Heme oxygenase-1: unleashing the protective properties of heme. Trends Immunol 2003;24:449-55.

32. Horvath I, Loukides S, Wodehouse T, Kharitonov SA, Cole PJ, Barnes PJ. Increased levels of exhaled carbon monoxide in bronchiectasis: a new marker of oxidative stress. Thorax 1998;53:867-70.

33. Kubes $\mathrm{P}, \mathrm{McC}$ afferty DM. Nitric oxide and intestinal inflammation. Am J Med 2000;109:150-8. 
DENEYSEL ÇALIŞMA - ÖZET

\title{
Siçanlarda oluşturulan yumuşak doku travma modelinde, hiperbarik oksijen ve ozon uygulamalarının doku iyileşmesi üzerine etkinliği: Deneysel çalışma
}

\section{Dr. Ali Osman Yıldırım, ${ }^{1}$ Dr. Mehmet Eryılmaz, ${ }^{2}$ Dr. Ümit Kaldırım, ${ }^{2}$ Dr. Yusuf Emrah Eyi, ${ }^{3}$ \\ Dr. Salim Kemal Tuncer, ${ }^{2}$ Dr. Murat Eroğlu, ${ }^{1}$ Dr. Murat Durusu, ${ }^{2}$ Dr. Turgut Topal, ${ }^{4}$ Dr. Bülent Kurt, ${ }^{5}$ Dr. Serkan Dilmen, ${ }^{6}$ Dr. Serkan Bilgiç, ${ }^{7}$ Dr. Muhittin Serdar ${ }^{8}$}

\author{
${ }^{1}$ GATA Haydarpaşa Asker Hastanesi, Acil Tıp Anabilim Dalı, İstanbul \\ 2GATA, Askeri Tıp Fakültesi, Acil Tıp Anabilim Dalı, Ankara \\ ${ }^{3}$ Hakkari Asker Hastanesi, Acil Servis, Hakkari \\ ${ }^{4}$ GATA, Askeri Tıp Fakültesi, Fizyoloji Anabilim Dalı, Ankara \\ ${ }^{5}$ GATA, Askeri Tıp Fakültesi, Patoloji Anabilim Dalı, Ankara \\ ${ }^{6}$ Elazığ Asker Hastanesi, Acil Servis, Elazığ \\ ${ }^{7}$ GATA Haydarpaşa Asker Hastanesi, Ortopedi ve Travmatoloji Anabilim Dalı, İstanbul \\ ${ }^{8}$ GATA, Askeri Tıp Fakültesi, Biyokimya Anabilim Dalı, Ankara
}

AMAÇ: Yumuşak doku travmaları bir çeşit akut travmatik iskemidir. Travmayla ortaya çıkan ödem, enflamasyon ve iskemiye, HBO ve ozonun olumlu etkileri olacağı düşünüldü.

GEREÇ VE YÖNTEM: Toplam 63 yetişkin erkek Sprague-Dawley türü sıçanın her birine başlangıçta yumuşak doku travması (YDT) uygulanmış sonrasında bir kısmına ozon, bir kısmına HBO tedavi prosedürü uygulandı. Prosedürler bitiminde doku ve kan örnekleri alınan hayvanlarda, doku oksidatif stres düzeyini tespitte doku LPO düzeyleri, antioksidan sistemin işlerliğini tespitte doku SOD ve GSH-Px enzim düzeyleri, histopatolojik olarak, enflamasyon ve ödemin tespitinde rutin hematoksilen-eozin boyaması kullanıldı.

BULGULAR: Oksijen konsantrasyonu arttığında azalan HIFI aktivitesine, antienflamatuvar etkilerinin olduğu gösterilen HO-I aktivitesine, her türlü akut olayda salınan iNOS aktiviteleri de çalışmamızda tespit edildi. Sonuç olarak, HBO ve ozon gruplarında LPO, iNOS düzeylerinde istatiksel olarak anlamlı azalma tespit ettik. Bu sonuçlarla uyumlu olarak histopatolojik incelemede de kontrol grubuna kıyasla HBO ve ozon gruplarında enflamasyonda anlamlı bir azalma ve her üç grupta ödemde anlamlı düşme mevcuttu.

TARTIŞMA: YDT'lerinde, HBO ve ozon tedavisinin çalısmamızdaki biyokimyasal ve histopatolojik bulgulara göre faydalı etkilerinin olduğu değerlendirilmektedir. Konuyla ilgili klinik çalışmaların yapılması etkilerinin daha iyi irdelenmesi adına faydalı olacağı söylenebilir.

Anahtar sözcükler: Deneysel; hiperbarik oksijen; ozon; yumuşak doku travması.

Ulus Travma Acil Cerrahi Derg 2014;20(3):167-175 doi: 10.5505/tjtes.2014.09465 